\title{
TINJAUAN EKONOMI ISLAM PADA PROSPEK INDUSTRI DAUR ULANG SAMPAH PLASTIK
}

\author{
Siti Musyahidah, ${ }^{1}$ Nia Manora Prasanti, ${ }^{2}$ Uswatun Hasanah ${ }^{2}$, \\ Ferdiawan Ferdiawan ${ }^{4}$ \\ ${ }^{1}$ Jurusaan Ekonomi Syariah, Fakultas Ekonomi dan Bisnis Islam, IAIN Palu \\ ${ }^{2}$ Jurusaan Ekonomi Syariah, Fakultas Ekonomi dan Bisnis Islam, IAIN Palu \\ 3 Jurusaan Ekonomi Syariah, Fakultas Ekonomi dan Bisnis Islam, IAIN Palu \\ ${ }^{3}$ Jurusaan Ekonomi Syariah, Fakultas Ekonomi dan Bisnis Islam, IAIN Palu
}

\section{ABSTRAK}

Tulisan ini membahas permasalahan perekonomian masyarakat dan permasalah sampah yang semakin mengganggu di kota Palu. Metode yang digunakan dalam penelitian ini adalah: metode pendekatan kualitatif deskriftif yang berisi gambaran tentang latar pengamatan, orang, tindakan, dan pembicaraan. Adapun sumber datanya adalah informan yaitu ketua anggota dan beberapa anggota yang bekerja di industri Tondo Mandiri. Adapun analisis data yang digunakan dalam penelitian ini adalah analisis deskriftif dengan menggambarkan dan menginterprensikan data dan temuan-temuan yang peneliti peroleh dari lapangan serta fakta-fakta yang ada. Hasil penelitian Tondo Mandiri tidak mempunyai prospek yang baik untuk kemajuan usaha kedepannya dikarenakan masalah dan hambatan yang dihadapinya. Kemudian ditinjau dari Ekonomi Islam Penulis memandang industri ini secara umum tidak bertentangan dengan ketentuan dalam syariat Islam, namun belum dapat sepenuhnya dikatakan sesuai dengan tinjauan Ekonomi Islam, karena ada beberapa hal yang dilakukan oleh para pekerja yang belum memenuhi syarat untuk dikatakan sesuai dengan aturan Syariat Islam.
INFORMASI

ARTIKEL

Katakunci:

Idustri daur ulang, sampah, ekonomi Islam, UKM 


\section{Pendahuluan}

Negara Indonesia adalah negara yang sedang berkembang dan masih berusaha untuk memajukan perkembangannya, termasuk dalam beberapa sektor perekonomian salah satunya ialah sektor perindustrian. Dalam kamus besar bahasa Indonesia industri merupakan pengolahan barang dengan menggunakan sarana dan peralatan, yang bertujuan untuk meningkatkan kemakmuran dan kesejahteraan rakyat serta membantu kelancaran atau kemajuan perekonomian negara. Sedangkan industrialisasi adalah penggalakan industri dalam negeri. Beberapa daerah di Indonesia telah terlebih dahulu memulai pergerakan ekonomi melalui industri-industri. Karna ada pendapat yang meyakini bahwa semakin maju suatu negara maka semakin maju pula sektor perindustrianya dan untuk dapat bersaing maju suatu negara harus melaksanakan industrialisasi. Oleh sebab itu industrialisasi dianggap sebagai suatu keharusan dalam mengatasi masalah pembangunan ekonomi di negara berkembang. ${ }^{1}$

Menteri Perikanan dan Kelautan Susi Pudjiastuti berdasarkan data yang diperoleh dari Asosiasi Industri Plastik Indonesia (INAPLAS) dan Badan Pusat Statistik (BPS), Ia mengatakan bahwa Indonesia adalah negara terbesar ke dua di dunia sebagai penyumbang sampah plastik yakni mencapai 64 juta ton/ tahun. $^{2}$

${ }^{1}$ Mudrajad Kuncoro, Ekonomika Industri Indonesia (Yogyakarta: ANDI, 2007), 7.

${ }^{2}$ Sherly Puspita, "Indonesia Penyumbang Sampah Plastik Terbesar Kedua di Dunia”, Artikel (Jakarta: Kompas, 2018), https://megapolitan.kompas.com/read/2018/08/19/211
Sementara itu dalam perekonomiannya masyarakat Kota Palu saat ini dihadapkan dengan beberapa permasalahan yakni ekonomi biaya tinggi, tingkat pengangguran tinggi, distribusi pendapatan yang tidak merata, dan tingkat kemiskinan yang tinggi. Hal tersebut menyebabkan kemampuan daya beli masyarakat yang lemah karena pendapatan yang rendah, industri padat karya yang ada sudah tidak memadai untuk mencapai tingkat pertumbuhan yang tinggi sehingga harus diarahkan pada industri yang padat modal, dan tingginya tingkat penggangguran karena kurangnya sumber daya tenaga kerja yang terlatih.

Dengan

perkembangan perekonominya masyarakat kota Palu tidak serta merta menyerah pada keadaan dan mereka masih tetap terus berusaha dengan beralih dan terjun serta melirik peluang usaha yang berbasis bisnis, dengan membuka industiindustri kecil, seperti industri dibidang kuliner dan juga industri-industri lainnya termasuk industri daur ulang sampah plastik, dengan harapan bisa meningkatan taraf hidup, membantu masyarakat yang lain dengan membuka lowongan kerja dan juga membantu pemerintah dalam mengentas kemiskinan. Islam juga menjelaskan dalam al-Quran tentang perintah bekerja, berusaha, dalam mencari rezeki dan karunianya diatas permukaan bumi ini dengan Ridho Allah, Sebagaimana yang terdapat dalam surah QS. AlJum'ah (62) : 10: yang terjemahannya:

"Apabila telah ditunaikan shalat, maka bertebaranlah kamu di

51811/indonesia-penyumbang-sampah-plastikterbesar-kedua-di-dunia, (diakses 28 Desember 2018). e-ISSN: $2686-6633$ 
muka bumi, dan carilah karunia Allah dan ingatlah Allah sebanyak-banyaknya supaya kamu beruntung" 3

Ayat ini menjelaskan tentang tuntutan ummat muslim untuk mencari rezeki yang telah diberikan oleh Allah Swt yang ada di muka bumi ini, karena dengan bekerja manusia dapat merubah kehidupan menjadi lebih baik lagi dan dengan bekerja pula dapat mengurangi kemiskinan yang dihadapi, dengan catatan pekerjaan harus sesuai syariah Islam. Ayat di atas sejalan dengan firman Allah swt tentang pemanfaatan segala sesuatu yang ada terdapat dalam QS. Al-Hadid (57) : 25 : yang terjemahannya:

"Sesungguhnya Kami telah mengutus Rasul-rasul Kami dengan membawa bukti-bukti yang nyata dan telah Kami turunkan bersama mereka Al kitab dan neraca (keadilan) supaya manusia dapat melaksanakan keadilan. dan Kami ciptakan besi yang padanya terdapat kekuatan yang hebat dan berbagai manfaat bagi manusia, (supaya mereka mempergunakan besi itu) dan supaya Allah mengetahui siapa yang menolong (agama) Nya dan rasul-rasul-Nya Padahal Allah tidak dilihatnya. Sesungguhnya Allah Maha kuat lagi Maha Perkasa". 4

Dari ayat di atas dijelaskan bahwa Allah telah menciptakan besi yang

\footnotetext{
${ }^{3}$ Departemen Agama Republik Indonesia, AlQur'an dan Terjemahnya, (Bandung: CV Penerbit Diponegoro, 2012), 554.
}

${ }^{4}$ Ibid., 541. padanya terdapat kekuatan yang hebat dan berbagai manfaat bagi manusia. Besi merupakan salah satu kekayaan alam yang disediakan oleh Allah SWT yang dapat diolah menjadi suatu yang bisa dijadikan bermacam-macam bentuk dan kebutuhan, serta manfaat yang begitu banyak. $^{5}$

Begitu juga halnya sampah plastik yang bisa digunakan kembali sesuai kebutuhan dan juga bisa dijadikan sebagai bahan olahan industri untuk dijadikan sesuatu yang bermanfaat dan bernilai ekonomis yang lebih tinggi.

Selain beraroma tidak sedap, sampah bisa menularkan berbagai macam penyakit kulit dan mencemari lingkungan dan masih banyak lagi. Dari sekian banyak efek negatif yang ditimbulkan oleh sampah ada juga efek positifnya yang dapat diambil dari sampah tersebut, salah satunya yaitu dengan mendaur ulang sampah plastik tersebut. Daur ulang merupakan proses pengambilan barang yang masih memiliki nilai dari sampah untuk digunakan kembali.

Tondo Mandiri yang terletak di kelurahan Tondo Kecamatan Mantikulore Palu Sulawesi Tengah, merupakan industri yang mengolah barang-barang bekas yang berbahan dasar plastik dengan beberapa langkah yaitu, mulai dari pengumpulan, pemisahan, pencucian, penggilingan, penjemuran, pengepakan dan dijual kembalii untuk dijadikan barang yang bisa digunakan kembali seperti barangbarang rumah tangga. Tondo Mandiri

${ }^{5}$ Abdul Malik Abdul Karim Amirullah, Tafsir Al-Azhar, (Surabaya: Yayasan Latimojong, 1981), 340. 
ini memiliki anggota kerja berjumlah 10 orang dan 1 orang pendamping, memiliki 1 mesin penggiling, dengan kapasitas produksi $600 \mathrm{KG}$ per hari.

Namun mereka juga mengalami hambatan dan tantangan yang menjadi masalah dalam mengolah daur ulang sampah tersebut, seperti cuaca buruk, listrik yang sering mati, air yang susah, mesin yang terbatas, dan yang paling utama menjadi halanganya adalah sumber daya manusianya (SDM) yang sangat kurang akan kesadaran untuk menjalankan usaha atau kariawannya yang tidak efektif dalam bekerja. ${ }^{6}$

\section{Metode Penelitian}

Metode merupakan suatu prosedur tata cara megetahui sesuatu yang mempunyai langka sistematis. ${ }^{7}$ Dalam penulisan karya ilmiah, penulis menggunakan metode pendekatan kualitatif dan jenis penelitian deskriptif. Metode kualitatif dapat digunakan untuk mengungkap dan memahami sesuatu di balik fenomena yang sedikit pun belum diketahui. Metode ini dapat juga digunakan untuk menambah wawasan tentang sesuatu yang belum diketahui. ${ }^{8}$ Peneliti dalam penelitian kualitatif ini akan mencoba mengerti makna suatu kejadian atau peristiwa dengan mencoba berinteraksi dengan

6Wawancara dengan Kepala Gudang Tondo Mandiri Jalan Soekarno Hatta. Bpk Ahmad Taufik Wilyanto, 36 Tahun. Tanggal 07 Desember 2018.

7 Muhammad, Metodologi Penelitian Ekonomi Islam Pendekatan kualitatif, (Jakarta: Rajawali PT. Raja grafindo Persada, 2008), 12.

8 Ansel Struss dan Julet Corbin, Dasar-Dasar Penelitian Kualitatif, (Yogyakarta : Pustaka pelajar, 2007), 5. orang-orang dalam situasi/fenomena tersebut.

Penggunakan metode kualitatif dalam penelitian ini dengan beberapa pertimbangan. Pertama, menyesuaikan metode kualitatif lebih mudah apabila berhadapan dengan kenyataan ganda. Kedua, dapat menyajikan secara langsung hakikat hubungan antara peneliti dengan informan'. Ketiga, Metode ini lebih peka dan lebih menyesuaikan diri dengan banyak penajaman pengarah bersama dan terhadap pola-pola nilai yang dihadapi. ${ }^{10}$

Penelitian ini dilakukan di Tondo Mandiri jalan Soekarno Hatta Kelurahan Tondo Kecamatan Mantikulore Kota Palu Sulawesi Tengah. Data dikumpul dengan menggunakan teknik observasi, wawancara mendalam yang melibatkan 11 orang keryawan dan pimpinan. Kemudian data juga dikumpulkan dari kajian dari berbabagi dokumen tertulis ${ }^{11}$. Sedangkan analisa data dilakukan dengan menggunakan teknik reduksi dan verifikasi dengan berbagai sumber data ${ }^{12}$. Data yang sudah

9 Nurdin, N. (2017a). Research in Online Space: The Use of Social Media for Research Setting Jurnal Sistem Informasi (Journal of Information System), 13(1), 6777.

10Ibid., 5.

11 Nurdin, N. (2017b). To Research Online or Not to Research Online: Using Internet-Based Research in Islamic Studies Context. Indonesian Journal of Islam and Muslim Societies, 7(1), 31-54.

12 Nurdin, N. (2016). The Roles of Information Technology in Islamic Bank Knowledge Management: A study of Two Syariah Banks in Palu. Hunafa: Jurnal Studia Islamika 13(2),

181-217. https://doi.org/https://doi.org/10.24239/jsi.v1 3i2.444.181-217

e-ISSN: $2686-6633$ 
direduksi kemudian dianalisis dengan mengaku pada konsep teori yang digunakan dalam penelitian ini.

\section{Hasil Dan Pembahasan}

\subsection{Prospek Industri Daur Ulang Sampah Plastik Tondo Mandiri Kota Palu}

Prospek adalah suatu peluang, kemungkinan, harapan atau kesempatan pada individu atau kelompok yang bertepatan dengan keadaan yang terjadi dalam kehidupanya.

Kemudian jika dikaitkan dengan bisnis (industri) prospek adalah kondisi yang akan dihadapi oleh perusahaan pelaku usaha dimasa yang akan datang dilihat dari potensi dan berbagai faktor pendorong dan penghambatanya sehingga terlihat seberapa besar peluang keuntungan yang mungkin terjadi atau sebaliknya yakni seberapa besar kerugian juga bisa terjadi. Prospek bisnis suatu usaha akan menunjukan kecenderungan untuk meningkat atau menutup suatu usaha itu sendiri, kondisi ini dipengaruhi oleh berbagai peluang dan ancaman yang dihadapi. Kelemahan dan kekuatan yang dimiliki pelaku usaha perusahaan sehingga diperlukan perencanaan dan perumusan strategis perusahaan secara baik. ${ }^{13}$

Untuk meningkatkan sebuah industri tidak akan terlepas dari peranan modal yang memadai, tenaga kerja yang professional, bahan industri yang baik dan memadai, proses produksi yang baik, sumber daya manusia yang baik, serta aspek pasar dan pemasaran yang

\footnotetext{
${ }^{13}$ Kasmir, Kewirausahaan, (Ed. Revisi, Jakarta: PT Raja Grafindo, 2012), 280.
}

tepat dan lancar. Dengan demikian kita bisa mengetahui bagaimana peluang industri ini kedepannya.

Untuk memulai bisnis tentunya memerlukan modal awal, namun industri daur ulang sampah plastik Tondo Mandiri ini adalah sebuah usaha bantuan dari pemerintah yakni Lembaga Pemberdayaan Masyarakat (LPM) Kota Palu. Namun pemerintah tidaklah memberikan bantuan sebanyak seratus pesen $(100 \%)$, bantuan yang diberikan oleh pemerintah adalah berupa 1 buah mesin penggiling sampah, bangunan industri, satu buah gerobak sampah, satu buah tangki air (tedmond), dan aliran listrik. Selain itu Pak Rully dan anggota lainya yang menyediakan lokasi/lapangan untuk industri kemudian patungan untuk modal awal membeli bahan baku dan alat-alat yang diperlukan lainya. ${ }^{14}$

Produksi sampah yang tinggi menyebabkan bisnis berbahan dasar sampah tidak pernah kehabisan bahan bakunya. Keunggulan lain dari usaha ini adalah bahan bakunya murah sehingga sangat berpengaruh pada harga hasil akhir produk daur ulang.

Tondo Mandiri sampai sekarang industri ini masih melakukan pengolahan sampai ke tahap bahan baku saja berupa pemecahan plastik-plastik dan semua ini tidak lepas dari hasil kerja tangan pekerjanya yang dibantu dengan 1 buah mesin penggiling, yang kemudian hasil olahan industri ini pun dijual kembali ke industri-industri lain yang lebih besar atau kepabrik-pabrik pembuatan barang-barang jadi. Dan

${ }^{14}$ Wawancara dengan Kepala Ketua Anggota Tondo Mandiri Jalan Soekarno Hatta. Bpk Rully, 32 Tahun. Tanggal 16 April 2019. 
sampai saat ini Tondo Mandiri ini dalam pengiriman barangnya masih menginduk pada Bank Sampah dalam menyalurkan hasil produksinya ke pabrik atau industri yang lebih besar yakni di kota Surabaya. ${ }^{15}$

Industri ini sampai sekarang mempunyai beberapa permasalahan dan hambatan baik internal maupun eksternal, seperti ${ }^{16}$ :

- Masalah mesin yang sering rusak akibat proses penyortiran dan pemecahan, yang biasanya ada biaya yang dikeluarkan untuk memperbaiki mesin tersebut.

- Cuaca buruk juga mempengaruhi jumlah hasil produksi, karena jika cuaca buru mereka tidak dapat mendapatkan hasil yang banyak dikarenakan hasil hasil produksi tersebut tidak dapat kering dalam hitungan waktu 1-2 hari

- Lampu yang sering mati menyebabkan mesin penggiling tidak dapat beroperasi.

- Keluhan warga setempat.

- Keamanan yang tidak baik di daerah tersebut karena telah dialami kejadian mesin penggiling dicuri sehingga menyebabkan aktivitas terganggu dan bahkan terhenti selama dua bulan setengah sehingga para anggota tidak mempunyai pemasukan atau pendapatan selama waktu tersebut.

- Serta permasalahan yang paling fatal dari industri ini ialah tidak

\footnotetext{
${ }^{15}$ Ibid.

${ }^{16}$ Wawancara dengan Kepala Ketua Anggota dan Anggota Tondo Mandiri Jalan Soekarno Hatta. Bpk Rully, Bpk, Ahmad Taufik Wilyanto, dan Bpk..... Tanggal 16 April 2019.
}

mempunyai manajemen organisasi yang baik untuk mempertahankan dan memperlancar jalanya kegiatan yang dilakukan.

Berdasarkan hasil penelitian, jika dilihat dari hasil perolehan bahan baku yang sekaligus membantu dalam kebersihan lingkungan, perekrutan tenaga kerja yang sekaligus membuka lapangan kerja dan mengurangi angka penganguran, kinerja karyawan yang bekerja dengan baik, keuntungan dari hasil penjualan yang dapat membantu perekonomian para anggota, dan sampai keuntungan yang diperoleh dapat diputar kembali menjadi modal pembelian bahan baku selanjutnyad dan menjadi modal untuk membuka pabrik yang lebih besar yaitu sebagai pabrik pembuat barang jadi dari bahan baku plastik dari bahan-bahan hasil olahan sendiri, serta menambah dan memperluas lokasi industri, dan memperbanyak jumlah karyawan. Maka dengan demikian seharusnya Tondo Mandiri bisa mengembangkan industrinya menjadi lebih besar.

Disamping dapat membantu perekonomian masyarakat setempat meningkat, membuka lapangan pekerjaan, dan ada lagi manfaat lainnya yaitu, mengurangi angka penganguran, dan membantu pemerintahan kota dalam menjaga kebersihan kota serta membantu dalam meningkatkan pendapatan daerah dalam sektor industri.

Jika semua itu dapat berjalan sesuai rencana dan lancar tanpa hambatan maka usaha ini memiliki prospek yang besar dan dapat merubah paradigma masyarakat untuk kedepannya, yang sebelumnya mungkin kita tidak mengetahui dan tidak sadar 
bahwa sampah plastik sangat bergunanya, serta ternyata memiliki peluang yang menjanjikan dan sangat besar dalam membantu meningkatkan perekonomian.

Namun jika tidak ada perbaikanperbaikan dalam industri tersebut dan tidak mempunyai pengelolaan manajemen yang baik, maka industri ini juga mempunyai prospek yang buruk kedepannya atau bahkan bisa terjadi penutupan lapangan usaha.

\subsection{Tinjauan Ekonomi Islam Terhadap} Prospek Industri Daur Ulang Sampah

Manusia dalam hidup pada dasarnya boleh melakukan apapun dalam bermuamalah (bertransaksi) atau berbisnis salah satunya dalam bisnis industri, selama industrinya itu terhindar dari hal-hal yang dilarang dalam syariat Islam itu sendiri, maka usaha atau bisnis tersebut adalah boleh untuk dilakukan.

Hamdi Agustin dalam bukunya studi kelayakan bisnis syariah mengatakan untuk melihat prospek suatu usaha ada beberapa faktor yang harus diperhatikan. Faktor-faktor tersebut yakni :

\section{Modal}

Dalam menjalankan suatu usaha, modal merupaka salah satu syarat yang penting dalam mengerakan sebuah usaha industri. Modal dalam artian sempit adalah sejumlah nilai yang dipergunakan untuk keperluan usaha. Modal dalam artian umum yakni mencakup benda-benda seperti tanah, gedung, mesin-mesin, alat-alat perkakas, dan barang produktif lainya untuk suatu kegiatan usaha. ${ }^{17}$

\section{Pada}

perencanaan, pengoganisasian, penerapan, dan pengawasan yang berhubungan dengan keuangan Islam mengatur ${ }^{18}$ :

- Setiap upaya dalam memperoleh harta harus memperhatikan caracara yang sesuai dengan syariah.

- Objek yang diusahakan bukan sesuatu yang diharamkan.

- Harta yang diperoleh digunakan untuk hal-hal yang tidak dilarang.

- Uang adalah sebagai alat tukar, bukan komonditas yang diperdagangkan.

Dalam memulai usahanya industri Tondo Mandiri dengan mendapatkan bantuan modal usaha dari pemerintah kota palu yakni Lembaga Pemberdayaan Masyarakat (LPM) dimana pemerintah memberikan bantuan berupa satu buah mesin penggiling sampah plastik, 1 buah tangki air, banggunan untuk industri, dan aliran listrik. Sehingga pak Rully dan anggota lain tinggal menyediakan halaman untuk tepat bangunan, modal awal untuk membeli bahan baku, dan membeli beberapa alat lainya yang diperlukan untuk menunjang pekerjaan dalam kegiatan produksi. ${ }^{19}$

${ }^{17}$ Mustafa Edwin, Maep, ET AL, Pengenalan Eksklusif: Ekonomi Islam, (Cet. 1; Jakarta: Kencana, 2007), h 253.

${ }^{18}$ Hamdi Agustin, Studi Kelayakan Bisnis Syariah, (Cet.1; Depok: Rajawali Pers, 2018), 116.

${ }^{19}$ Wawancara dengan Ketua Anggota Tondo Mandiri Jalan Soekarno Hatta. Bpk Rully, 32 Tahun. Tanggal 16 April 2019. 
Jurnal Ilmu Ekonomi dan Bisnis Islam - JIEBI

Vol.1 No. 1 Tahun 2019

Tabel 1

Spesifikasi Modal Industri Daur Ulang Sampah Plastik

\begin{tabular}{|c|l|c|c|}
\hline No & $\begin{array}{c}\text { Nama Alat } \\
\text { (Modal) }\end{array}$ & Satuan & \multicolumn{1}{|c|}{ Nilai (Rp) } \\
\hline 1 & $\begin{array}{l}\text { Mesin } \\
\text { Penggiling }\end{array}$ & $\begin{array}{c}1(50 \\
\text { KG/ } \\
\text { Jam) }\end{array}$ & Rp. 18.000.000 \\
\hline 2 & Tangki Air & $\begin{array}{c}(1000 \\
\text { L) }\end{array}$ & Rp. 2.200.000 \\
\hline 3 & Gerobak & 1 & Rp. 700.000 \\
\hline 4 & $\begin{array}{l}\text { Modal Awal } \\
\text { Beli Bahan } \\
\text { Baku }\end{array}$ & Rp. 3.500.000 \\
\hline 5 & Aliran Listrik & & Rp. 700.000 \\
\hline 6 & $\begin{array}{l}\text { Alat-alat } \\
\text { lainya }\end{array}$ & Rp. 1.000 .000 \\
\hline \multicolumn{3}{|c|}{ Jumlah } & $\mathbf{2 6 . 1 0 0 . 0 0 0}$ \\
\hline
\end{tabular}

Dari tabel di atas adalah jumlah modal yang diperlukan apabila ingain membuka sebuah industri daur ulang sampah plastic dengan kafasitas seperti Tondo Mandiri. Namun jumlah diatas belum termasuk pada lahan untuk bangunan dan bangunan itu sendiri yang jumlah nilainya tergantung dengan harga tanah ditempat yang akan kita bangun dan juga harga bahan bangunan pada daerah tersebut. Pada penelitian, apabila ditotalkan jumlah diatas dan ditambah dengan lahan kurang lebih 500 Meter dan Bangunan yang layak maka diperlukan modal kurang lebih Rp.65.000.000. ${ }^{20}$

Jadi, dalam hal modal tidak ada sesuatu hal yang dilarang menurut syariat Islam, yakni modal tidak mengandung unsur Riba, tidak ada ketidak jelasan karna semua bantuan yang diberikan dicatat secara jelas oleh anggota, dan tidak ada yang merasa terzdalimi atas adanya patungan untuk modal awal karena semua anggota

\footnotetext{
${ }^{20}$ Wawancara dengan Ketua Anggota Dan Kepala Gudang Tondo Mandiri. Bapak Ruly dan Ahmad Wilyanto. Tanggal 16 April 2019.
}

sepakat untuk jumlahnya, dan juga tidak terdapat unsur judi didalamnya.

\section{Tenaga Kerja}

Tenaga kerja adalah segala usaha dan ikhtiar yang dilakukan oleh anggota badan atau fikiran untuk mendapatkan imbalan yang pantas. Termasuk semua jenis kerja yang dilakukan fisik atau pikiran. Tenaga kerja sebagai salah satu faktor produksi mempunyai arti yang besar. $^{21}$

Karena semua kekayaan alam tidak berguna bila tidak diolah oleh manusia. Alam telah memberikan kekayaan yang tidak terhitung tetapi tanpa usaha manusia semua akan tersimpan dan tidak bermanfaat.

Islam mendorong ummatnya untuk bekerja dan memproduksi, bahkan menjadikannya sebagai sebuah kewajiban terhadap orang-orang yang mampu, lebih dari itu Allah akan memberi balasan yang setimpal yang sesuai dengan amal/kerja sesuai dengan firman Allah Swt dalam Q.S an-Nisaa (4) : 58:

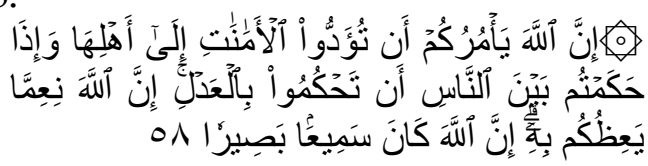

“Sesungguhnya Allah menyuruh kamu menyampaikan amanat kepada yang berhak menerimanya, dan (menyuruh kamu) apabila menetapkan hukum di antara manusia supaya kamu menetapkan dengan adil. Sesungguhnya Allah memberi pengajaran yang sebaik-baiknya kepadamu. Sesungguhnya Allah

${ }^{21}$ Mustafa Edwin, Maep, ET AL, Pengenalan Eksklusif: Ekonomi Islam, h. 420. 
adalah Maha Mendengar lagi Maha Melihat" 22

Kandungan ayat tersebut menyampaikan amanat kepada yang berhak menerimanya, yaitu orang yang mempunyai keahlian di bidang tersebut. Karena menempatkan seseorang sesuai dengan keahlianya merupakan salah satu karakteristik profesionalisme dalam Islam. Karena Ia mempunyai kemampuan dan keterampilan dalam melaksanakan suatu pekerjaan. ${ }^{23}$

Pada hasil penelitian, tenaga kerja pada Tondo Mandiri adalah para anggota yang mendirikan industri tersebut yang mana pada awalnya anggota yang bekerja sebanyak 10 orang dan saat ini hanya tersisa lima orang dengan satu orang pengganti dan juga dibantu oleh satu alat mesin penggiling. Manajemen pembagian kerja pada industri ini belum baik karena tidak ada pembagian pekerjaan dengan pembagian masing-masing. Yang paling banyak bekerja adalah siapa yang rajin dan disiplin, adapun dalam hal waktu mereka tidak menetapkan waktu yang baik sebagaimana para pekeja mereka datang semaunya namun mereka datang masing-masin, jadi kadangkadang pekerjaan mereka maksimal dalam sehari kadang juga terabaikan. Sedangakan pada segi profesionalisme para pekerja industri Tondo Mandiri ini bukan orang-orang yang berpendidikan dan ahli dalam hal pengelolaan sampah itu sendiri namun jika dilihat dari sisi

\footnotetext{
${ }^{22}$ Departemen Agama Republik Indonesia, Al-Qur'an dan Terjemahnya, (Bandung: CV Penerbit Diponegoro, 2012), 58. Syariah., 50.
}

pengeerjaannya tidaklah memerlukan orang yang benar-benar ahli karena semua pekerjaan yang dilakukan dapat dilakukan oleh orang-orang biasa selama Ia mau belajar dan berusaha.

\section{Aspek Bahan Baku}

Industri Tondo Mandiri adalah sebuah industri yang mengelolah sampah plastik menjadi bahan yang lebih bernilai. Bahan baku yang diolah di industri ini adalah plastik-plastik bekas atau bahkan telah menjadi sampah pada masyarakat kebanyakan yang kemudian diolah dengan beberapa prosesnya sehingga menjadi bahan setengah jadi.

Begitupula dengan plastik yang pada dasarnya dapat digunakan kembali meskipun telah menjadi bahan bekas, maka sebagai manusia kita mestilah memanfaatkan apapun yang ada disekitar kita dengan sebaik mungkin.

Tidak susah untuk mencari bahan baku yang akan diproduksi para anggota yang bekerja di Tondo Mandiri biasanya mereka mendapatkan bahan baku dari para pemulung, ibu rumah tangga, dan tempat pembelian sampah plastik yang ada di Kota Palu. Atau pada beberapa kesempatan para anggota mengumpulkan sendiri bahan baku yang akan mereka kelolah. ${ }^{24}$

Dengan demikian tondo mandiri telah melaksanakan perintah dalam Islam untuk memanfaatkan segala sesuatunya yang ada dengan baik, dengan adanya industri ini banyak manfaat yang didapat baik oleh

${ }^{24}$ Wawancara dengan Anggota Pekerja Tondo Mandiri Jalan Soekarno Hatta. Bapak Fadli, 17 Tahun. Tanggal 15 April 2019. 
Jurnal Ilmu Ekonomi dan Bisnis Islam - JIEBI

Vol.1 No. 1 Tahun 2019

masyarakat sekitar maupun para anggota yang bekerja di industri tersebut.

\section{Proses Pelaksanaan Kerja ( Proses} Produksi )

Dalam Islam bekerja adalah kewajiban bagi seluruh manusia yang hidup dimuka bumi ini, manusia diwajibkan mencari nafkah untuk menunjang kebutuhan hidup sehari-hari dan berikhtiar dalam menjalani pekerjaan pada akhirnya Allah lah yang menentukan hasilnya selama manusia tersebut telah berusaha maka Allah tidak akan menyianyiakan usaha umat Nya tersebut. Dalam Islam semua tata cara dalam menjalani kehidupan telah diatur tentunya dalam bekerjapun telah ada hal-hal yang di anjurkan dalam syariat untuk dilakukan atau tidak, pada hal lain saat bekerja haruslah mengerjakan sesuatu yang baik dan halal zat ataupun prosesnya. ${ }^{25}$

Dalam penelitian proses pelaksaan kerja atau proses produksi yang dilaksanakan di Tondo Mandiri yakni :

a. Penerimaan Pembelian Bahan Baku

Para anggota industri Tondo Mandiri membeli bahan baku berbahan dasar plastik pada dasarnya plastik bekas dari para pemulung di kota Palu dengan cara menjemput bahan dari rumah-rumah, dari para pemulung, menerima pembeliaan langsung di industri, ataupun hasil dari beberapa tempat yang mereka cari sendiri. Adapun harga beli bahan baku ini berbeda-beda, tergantung pada kualitas

${ }^{25}$ Nurdin, N., Novia, N., Rahman, A., \& Suhada, R. (2019). Potensi Industri Produk Makanan Halal Di Kota Palu. Jurnal Ilmu Ekonomi dan Bisnis Islam, 1(1), 1-12. dari plastik yang dibeli atau yang dijual oleh para penjual yakni berkisaran dari Rp.2.500- Rp.3.000. dan setaleh proses produksi yang dilakukan di Tondo Mandiri plastik bekas tadi dijual kembali seharga Rp. 13.000- Rp. 15.000. b. Pemecahan Barang / Bahan Baku Setelah ada bahan baku (plastik bekas) maka langkah selanjutnya adalah disortir berdasarkan jenis-jenis plastik agar mesin tidak mudah rusak. Setelah disortir bahan baku tersebut dipecahpecahkan dengan menggunakan alat seperti kapak kecil, obeng, tang, yang telah disediakan. Hal ini akan mempermudah saat penggilingan.

c. Penggilingan

Merupakan bagian penting dalam proses produksi, setelah melewati langkah-langkah di atas, barulah bahan baku siap untuk digiling dengan mesing penggiling, hasil dari gilingan tersebut berbentuk pecahan-pecahan kecil, yang kemudian diangkat dengan menggunakan wadah yang menyerupain saringan agar terpisah antara hasil yang diperoleh dengan sampah.

d. Penjemuran

Kemudian pecahan-pecahan bahan baku tersebut di jemur dan dikeringkan di atas terpal yang telah dibentangkan dibawah sinar matahari selama kurang lebih 1-3 hari sessuai dengan cuaca yang terjadi.

e. Pengepakan dan Pemasaran

Merupakan bagian terakhir dari proses produksi. Setelah proses penjemuran benar- benar kering, bahan baku tersebut di masukan ke dalam Karung dan di timbang dan kemuadian siap untuk di pasarkan kembali.

Dari beberapa langkah-lngkah kerja yang telah disebutkan diatas tidak e-ISSN: 2686-6633 
ada pekerjaan yang bertentangan dengan Syariat Islam ataupun merugikan para pekerja. Dalam hal jual beli mereka melakukannya atas dasar suka sama suka, dengan ini peneliti telah menanyakan langung kepada beberapa penjual bahan baku dan atau para pemulung. Mereka merasa diuntungkan dengan adanya tempat penjualan sampah plastik tersebut yang mana tadinya plastik bekas hanya menjadi sampah yang mencemarkan lingkungan dengan adanya yang membeli maka mereka di untungkan baik dalam segi ekonomi maupun segi kebersihan lingkungan. ${ }^{26}$

\section{Penyaluran Hasil Produksi Pemasaran )}

Pemasaran dalam persektif Islam adalah sebuah disiplin bisnis strategi yang mengerahkan proses penciptaan, penawaran, dan perubahan value dari satu inisiator kepada stakholdernya, yang dalam keseluruhan prosesnya sesuai dengan akad dan prinsip-prinsip muamalah dalam islam. Kata kunci dalam definisi pemasaran syari'ah ini adalah bahwa dalam seluruh proses, baik proses penciptaan, proses penawaran maupun proses perubahan nilai (value), tidak boleh ada yang bertentangan dengan akad dan prinsipprinsip muamalah dalam islam. ${ }^{27}$

Pemasaran adalah suatu aktivitas yang selalau dikaitkan dengan perdagangan. Ada beberapa etika yang

\footnotetext{
${ }^{26}$ Wawancara dengan Anggota Pekerja Tondo Mandiri Jalan Soekarno Hatta. Bapak Rinaldi Saloke, 17 Tahun. Tanggal 16 April 2019.

${ }^{27}$ Muhammad Syakir Sula, Asuransi Syari'ah (Jakarta: Gema Insani, 2004), h. 425.
}

harus dijunjung oleh pedagang Muslim dalam menjalankan aktivitas jual-beli, yakni tidak boleh menjual sesuatu yang haram, tidak melakukan sistem perdagangan terlarang, tidak terlalu banyak mengambil untung, tidak bersumpah palsu, tidak berbohong ketika berdagang, tidak mengurangi timbangan, dan tidak boleh melakukan monopoli untuk kepentingan yang tidak benar. ${ }^{28}$

Berdasarkan hasil penelitian, industri Tondo Mandiri menyalurkan hasil dari produksinya setiap 3-4 minngu satu kali dengan jumlah ratarata penjualan sebanyak 1,5 Ton setiap pengiriman. Sampai saat ini dikarenakan Tondo Mandiri belum mempunyai kendaraan sendiri untuk menyalurkan hasil produksinya maka industri ini mengirim atau menjual bahannya dengan cara menginduk pada industri daur ulang sampah plastik yang telah mempunyai alat untuk mengirim sendiri yakni Bank Sampah yang ada dikelurahan Duyu dengan cara membayar biaya pengiriman kepada industri tersebut. ${ }^{29}$

\section{Kesimpulan}

Prospek Industri Daur Ulang Sampah Plastik Tondo Mandiri Kota Palu dilihat dari peluang pasar yang cukup menjanjikan ditambah dengan bahan baku berupa plastik bekas yang banyak bahkan tidak habis-habis dalam lingkungan masyarakat, serta sektor pemasaran yang mudah, dan dilihat dari

${ }^{28}$ Hamdi Agustin, Studi Kelayakan Bisnis Syariah., 87-88.

29Wawancara dengan Ketua Anggota Tondo Mandiri Jalan Soekarno Hatta. Bpk Rully, 32 Tahun. Tanggal 16 April 2019.

e-ISSN: 2686-6633 
cara kerjanya (produksi) yang tidak memerlukan keahlian yang begitu mendalam/dapat dikerjakan oleh siapa saja.

Seharusnya Tondo Mandiri mempunyai prospek yang sangat besar untuk dikembangankan dan ditingkatkan kedepanya. Sehingga dapat membantu perekonomian masyarakat setempat meningkat atau mengurangi angka kemiskinan, membuka lapangan pekerjaan, dan ada lagi manfaat lainnya yaitu, mengurangi angka penganguran, dan membantu pemerintahan kota dalam menjaga kebersihan kota serta membantu dalam meningkatkan pendapatan daerah dalam sektor industri.

Namun dari lima aspek yang disebutkan oleh Hamdi Agustin dan Sugiyono dalam buku Studi Kelayakan bisnis bahwa yang paling penting dalam melihat prospek kemajuan sebuah usaha adalah aspek sumber daya Insani atau sumber daya manusianya sebagai penggerak semua kegiatan yang ada di Industri.

Kemudian Tondo Mandiri mempunyai hambatan yang menjadi permasalahan dari para pekerjanya yang tidak tekun dan tidak disiplin. Permasalahan tersebut berakibat tidak baik untuk kelangsungan kemajuan industri ini nantinya maka penulis menyimpulkan bahwa prospek pengembangan usaha pada Tondo Mandiri jalan Soekarno Hatta. Tidak mempunyai prospek yang baik untuk kemajuan dan pengembangan usaha kedepannya. Jika tidak ada perbaikan dalam segi tenaga kerja dan juga manajemen yang terstruktur.

\section{Daftar Pustaka}

Al-Qur'anul Karim dan Terjemahanya. Ahmadi, Ruslam. Metodelogi Penelitian Kualitatif. Yogyakarta: Ar-Ruzz Media, 2014.

Ali, Zainuddin. Hukum Ekonomi Syariah. Jakarta: Sinar Grafika, 2009.

Ali, Zainuddin dan Zainuddin, Anwar. Etika Ekonomi Islam. Palu: Yayasan Masyarakat Indonesia Baru, 2016.

Agustin, Hamdi. Studi Kelayakan Bisnis Syariah. Cet.1, Depok: Rajawali Pers, 2018.

Amirullah Karim Abdul, Malik Abdul. Tafsir Al-Azhar. Surabaya: Yayasan Latimojong, 1981.

Amirullah Karim Malik Abdul. Tafsir Al-Azhar. Jakarta: Pustaka Panjimas. 1983.

Arikunto, Suharsimi. Prosedur Penelitian Suatu Pendekatan Praktek. Jakarta: Rineka Cipta, 1998.

Arifin, Bustanul. Hukum Islam di Indonesia. Cet.1, Jakarta: Universitas Yashi. 1998.

Dumairy. Perekonomian Indonesia. Jakarta: Erlangga,1996.

Departemen Agama Republik Indonesia. Al-Qur'an dan Terjemahanya. Bandung: $\quad C V$ Penerbit Diponegoro, 2012.

Edwin, Mustafa, Maep, ET AL. Pengenalan Eksklusif: Ekonomi Islam. Jakarta: Kencana, 2007.

Efendi, Mochtar. Ekonomi Islam Suatu Pendekatan Berdasarkan Ajaran Qur'an dan Hadis. Palembang: Yayasan Pendidikan dan Ilmu Islam Al-Mukhtar, 1996.

Euis, Amalia. Keadilan Distribusi dalam Ekonomi Islam. Jakarta: Raja Grafindo Persada, 2009. 
Kasmir. Kewirausahaan. Jakarta: Rajawali Pers, 2013.

Kasmir. Kewirausahaan. Ed. Revisi, Jakarta: PT Raja Grafindo. 2012.

Kuncoro, Mudrajad. Ekonomika Industri Indonesia. Yogyakarta: ANDI, 2007.

Nurdin, N. (2016). The Roles of Information Technology in Islamic Bank Knowledge Management: A study of Two Syariah Banks in Palu. Hunafa: Jurnal Studia Islamika, 13(2), 181217.

https:/ / doi.org/https://doi.org/ 10.24239/jsi.v13i2.444.181-217

Nurdin, N. (2017a). Research in Online Space: The Use of Social Media for Research Setting Jurnal Sistem Informasi (Journal of Information System), 13(1), 67-77.

Nurdin, N. (2017b). To Research Online or Not to Research Online: Using Internet-Based Research in Islamic Studies Context. Indonesian Journal of Islam and Muslim Societies, 7(1), 31-54.

Nurdin, N., Novia, N., Rahman, A., \& Suhada, R. (2019). Potensi Industri Produk Makanan Halal Di Kota Palu. Jurnal Ilmu Ekonomi dan Bisnis Islam, 1(1), 1-12.

Sabiq, Sayyid. Membumikan PrinsipPrinsip Islam. Surabaya: Karya Agung Surabaya, 2010.

Sula, Muhammad Syakir Sula. Asuransi Syari'ah. Jakarta: Gema Insani. 2004.

Suryabrata, Suryadi. Metodelogi Penelitian. Jakarta: Raja Grafindo Persada, 1998.

Qodratillah, Taqdir Meity dkk. Kamus Besar Bahasa Indonesia Untuk Pelajar. Jakarta: Badan
Pengembangan dan Pembinaan Bahasa, Kementrian Pendidikan dan Kebudayaan, 2011

Nuryani, Asih. Jadi Jutawan Modal Sampah Plastik. Yogyakarta:

Penerbit Pustaka Grhatama, 2010.

Subagyo, P Joko. Metode Penelitian Dalam Teori dan Praktek. Jakarta: Rimeka Cipta, 1997.

Hilbert, David. Daur Ulang. (Buku Jurnal Berbahasa Indonesia). http:// daur-ulang.dy.web.id (diakses 13 Desember 2018).

Academi, Graedu. Pengertian Prospek Bisnis dari Berbagai Pandangan dan Segala Sisi, (Surabaya: Groedu Inti Global Inovasi , 2016), diakses (9 Desember 2018).

Putra Purnama, Hijrah dan Yuriandala, Yebi. "Studi Pemanfaatan Sampah Plastik Menjadi Produk dan Jasa Kreatif'. (Sains dan Teknologo Lingkungan Jurusan Tehnik Lingkungan Universitas Islam Negeri Yogyakarta, 2010), www.researchg.net/publication $\angle 309749015 \quad$ diakses (13 Desember 2018).

Putra Purnama, Hijrah dan Yuriandala, Yebi. "Studi Pemanfaatan Sampah Plastik Menjadi Produk dan Jasa Kreatif'. (Sains dan Teknologo Lingkungan Jurusan Tehnik Lingkungan Universitas Islam Negeri Yogyakarta, 2010), www.researchg.net/publication $\angle 309749015 \quad$ diakses (13 Desember 2018).

Sulistiyorini Rahmawati, Nur dan Saputra, Rudi. "Partisipasi Masyarakat Dalam Pengelolaan Sampah Di Lingkungan Margaluyu 
Kulurahan Cicurug". (Share Social Work Jurnal). http://jurnal.unpad.ac.id/share /article/download/13120/5984 (diakses 13 Desember 2018). Daur Ulang Sampah, https://id.wikipedia.org/wiki/ Pengelolaan_sampah, di akses ( 10 Desember 2018).

Aisyah, Tri Yana. "Analisis Kelayakan Dan Strategi Pengembangan Usaha Industri Rumah Tangga Keripik Belut Dikecamatan Godean Kabupaten Seleman". (Yogyakarta: Universitas Islam Negeri (UIN) Sunan Kalijaga, 2017). (diakses 8 Desember 2018).

Hafiz, Abdul. "Tinjauan Ekonomi Islam Terhadap Prospek Pengembangan Usaha Kerupuk Dalam Meningkatkan Perekonomian
Masyarakat di Desa Gelogor Kecamatan Kediri Kabupaten Lombok Barat" (Mataram: Universitas Islam Negeri (UIN) Mataram ,2017. ( diakses 8 Desember 2018)

Purbasari, Nurul "Pemberdayaan Masyarakat Melalui Kegiatan Daur Ulang Sampah Plastik". (Jakarta: Universitas Islam Negeri Syarif Hidayatullah, 2014), diakses ( 9 Desember 2018).

Rofl'ah, Syafa'atur. " Pemberdayaan Masyarakat Melalui Pengelolaan Sampah (Studi di Bank Sampah Surolaras, Suronatan, Kelurahan Notoprajan, Kecamatan Ngampilan, Yogyakarta)". (Yogyakarta: Universitas Islam Negeri (UIN) Sunan Kalijaga,2013). diakses (8 Desember 2018). 